\title{
Actualities of balance diagnostics system model development for persons with disabilities
}

\author{
Aleksandrs Gorbunovs, Bruno Zuga, Janis Kapenieks (sn.), Atis Kapenieks, Rudolfs Gulbis, \\ Zanis Timsans \\ Distance Education Study Centre, Riga Technical University. \\ Address: Kronvalda Blvd. 1, Riga, LV-1001, Latvia
}

\begin{abstract}
In Latvia so far there have not been made comprehensive studies to provide balance function diagnostics for persons with disabilities. It is also recognized that there is a lack of dedicated efficient and widely accessible for patients systems, equipment and tools to make balance function and dysfunction diagnostic, as well an improvement of the patients' movement capabilities. This position paper gives an overview about the latest technical engineering solution trends and developments in the world, which could be suited and developed to create the conformable new, rather simple, accessible and cheap systems. Such systems will have to ensure the diagnostics of balance function for persons with disabilities and encourage them the usage of mentioned equipment to particular balance and movement functionality.
\end{abstract}

Keywords: balance disorder, controller, disability, sensor.

\section{INTRODUCTION}

At the moment, according to the United Nations and World Bank data, approximately 15 per cent of the whole world population are living with some kind of disability [1], and about 3 per cent of them have significant disabilities [2]. Besides, population aging tendency makes these proportions even worse. The most unfavourable situation is in the group of the world's poorest countries and among indigent population where one fifth of residents are disabled [3]. One of the eight persons in European Union is either with disabilities or chronically ill [4]. And what is more unacceptably, 75 per cent of people with severe disabilities are outside European labour market [5]. During a year more than 3 per cent of the workers in the European Union and European Economic Area get injuries at the workplace [6].

Economic and Social Council of the United Nations (UN) in its Resolution has drawn the attention to the necessity of removing any barriers to the thorough participation of persons with disabilities in society activities and their employment ensuring equal rights and opportunities [7]. Integration of persons with disabilities as much as possible in society activities is declared by the UN "Convention on the Rights of Persons with Disabilities" [8]. This is the UN strategic course of action [9]. In November 2010 European Commission launched similar strategy, so-called Disability Strategy 2010-2020 [10].
Noted UN statement challenges countries and municipalities getting back to work persons with disabilities. It includes wide range of activities and necessity to work out policy documents at the regional level. Various formal and informal reintegration tools should be used to ensure rehabilitation and retention of persons with chronic disease, injuries and disabilities [6].

However, still now persons with disabilities have not sufficient possibilities to return back to work, acquire new professional competences, het a real labour, social and leisure equity. Rehabilitation and retention processes are not going quick enough. Provided service still needs to be improved; it does not satisfy quantitative and qualitative needs of persons with disabilities [11]. Appropriate continual medical and physiotherapeutic actions and care can hasten rehabilitation process.

Variety of patients' supporting tools and systems are also aimed to help for persons with disabilities. However, abovementioned United Nations and European Commission strategies urge researchers to develop new innovative technical solutions. The aim of this position paper is to direct attention to the necessity of creating low-cost helpful efficacious system which would ensure balance diagnostics and balance functions improvement for people with disabilities. 


\section{TOOLS AND METHODS}

\section{A. Theoretical background of human balance characteristic parameters and control methods}

Human imbalances can be described by the inverted pendulum model. It is used to determine the gravity and acceleration perturbations. If they are identified, it would be possible to determine motoric mechanisms which could allow protecting against abovementioned perturbations [12].

The measurement of the position of the body is carried out by quantifying changes of the centre of gravity in direction from the front to rear and middlelateral deflection. In the inverted pendulum model the balance dynamic comprises deflections both from the front to rear and from the middle to lateral. The model includes the acceleration controlled by the weight, and perturbations caused by gravitation [13].

Human balance mechanism controls the position of the separate centre of gravity of each foot in respective room area. If this mechanism detects the position deflection of the centre of gravity from admissible value, corresponding muscle group receives a signal which ensures a return to the equilibrium state [13].

If balance control mechanism is not able to control deflections of the centre of gravity effectively enough, balance disorders will appear. Then appropriate technological solutions might help people and allow them controlling wittingly the deflection from admissible norms, and as a result, maintaining the equilibrium state. Accordingly, automatic feedback, which ensures keeping the balance, would be substituted with the conscious balance control. And that could be supported by technological solutions. Besides, over time the conscious balance control will become as a habit of balance ensuring.

The balance ensuring mechanism controls decrease and increase of the load onto a straight line which connects human centre of gravity with the spots under each foot. If the angles between the lines are correct, the lines of the force increasing-decreasing lines are situated in the related tandem positions, and the ankle muscles control them independently. In the interim state the lines exist but the ankle muscles control processes are not orthogonal ones; usually they work at approximately 60 degree angle. The direction and force increasing-decreasing lines control of the ankles allows fixing the muscle groups' activity adding points which are responsible for the ankles position and balance ensuring mechanism in the rest state in different positions [13].

Human balance capabilities might be improved by rather simple user's centre of pressure measurement tool which is known as the centre of pressure and complexity monitoring system (CPCMS). It ensures both data collection and analysis $[14,15]$.
The coordinates of the centre of pressure (COP) are calculated, taking into account generated reaction force which is an outcome from four pressure sensors F1, F2, F3, F4, using the formula: $\mathrm{W}=\mathrm{F} 1+\mathrm{F} 2+\mathrm{F} 3+$ $\mathrm{F} 4$, where $\mathrm{W}$ is the reaction force, and $\mathrm{COP}=(\mathrm{X}, \mathrm{Y})$ where $\mathrm{X}$ and $\mathrm{Y}$ - respective directions. Further, if a distance between the sensors is $\mathrm{L}$, then the COP location could be calculated using formulas as follows [15]:

$$
\begin{aligned}
& X=\frac{[(F 4+F 2)-(F 1+F 3)] \times L}{W} \\
& Y=\frac{[(F 3+F 4)-(F 1+F 2)] \times L}{W}
\end{aligned}
$$

\section{B. Balance testing systems and tools}

Existing balance systems can be divided into two main groups: deep muscle training equipment (spheres, discs, soft platforms, etc.) and digital balance testing systems (Biosway, DBA (Digital Balance Analyser), ICS Balance Platform, etc.). Training equipment strengthens musculature which is responsible for keeping of balance but do not provide diagnostic information. Besides, there is also not possible to detect and register ongoing change dynamics with training equipment. Digital systems are designed for very precise balance function measurement. These data can be used in scientific research. Unfortunately, such systems are not widely available due to the high price. Therefore, the necessity of creating user-friendly, cheap and data assessable system is activated. Planned balance training system prototype might be developed also taking into account widely available nowadays mobile devices and built-in sensors.

The United States company Biodex introduces powerful and efficacious equipment Balance System $^{\text {TM }}$ SD which can satisfy needs of wide range of its users. It is not limited for medical purposes only, and can help in balance diagnostics and improvement both for athletes, persons with disabilities, and everybody who looks for the improvement of balance capabilities and development of muscle tone. It is also aimed to help people with injures to improve their kinaesthetic abilities. Five test options and six training activities are provided [16, 17].

Balance diagnostics and exercises are implemented on the special surface platform which can be used to measure both static and dynamic balance capabilities. To ensure users safe on-off movement, it is equipped with locking mechanism. For safety purposes adjustable support handles are also installed. The data, received from the placed in the platform set of sensors, reach high resolution colour touch screen LCD display which allows patients monitoring their exercise progress. All diagnostics results can be recorded and sent to print [17]. 
However, Balance System ${ }^{\mathrm{TM}} \mathrm{SD}$ ought to be recognized mainly as the stationary system. Regardless of small wheels, attached to the platform, which make system movement process much easier, it remains still rather uncomfortable for relocation due to its weight and dimensions.

Another Biodex development in the form of Biosway system with lightweight platform can solve relocation problem. It is produced as portable equipment and can be transported in a couple bags. However, even this advantage does not allow patients with disabilities moving on their own $[18,19]$.

There are also attempts to create more compact and suitable for daily use tools. Researchers have developed some balance testing systems which put to use the sensors already embedded in mobile phones. In practice this works so that the phone is secured on the body with a longer splint and the range of movement anomalies are summarised in a time period.

Balance problem solving application software for mobile phones and tablets might be divided into two groups: a) for performing measurements and b) training. To illustrate both practical applications further in this sub-chapter we will give some examples.

For example, Visual Vertical application software supports balance measurement [20]. It could be installed into iPhone or iPad. These devices ought to be inserted and fixed at the bottom of the opaque bucket. The aim of the use of the basket is to limit patient's view angle and prevent observation of surroundings during the test. Patient's task is, looking at the red line, to amend the bucket so that the line is vertical. The patient must perform this task initially with both eyes and then with each eye separately. The measurement is displayed in degrees for the deviation from vertical. As the measurements might not be precise enough, it is suggested to perform this test several times; the average value is calculated by noted application. The application is cheap (USD 14,99). Pursuant to that, despite some inaccuracies the tool may tempt customers to choose it.

Another balance measurement system iBest is designed on the Android mobile operating system (OS) base and is for mobile devices to be used in this OS. IBest consists of three main components: mobile device, data storage cloud server and Web technology interface. Mobile device offers information about an exercise, detects and evaluates balance and sway abnormality by using of sensors embedded into smart phone, and gives feedback in audio form. Storage server performs trend analysis from the user's profile saved data. Web interface ensures therapists' access to the patients' data and statistics. The system employs three sensors: acceleration, gyroscope, and magnetometer ones; the combination of all these sensors allows getting a higher accuracy [21]:
- Acceleration sensor provides speed and position change tracking. Multiple axes accelerometer also can be used as the orientation sensor in the same plane,

- Gyroscope sensor allows measuring orientation or rotation speed changes,

- Magnetometer sensor like compass provides absolute orientation in space.

The primary function of the iBest device is to help those patients who want to continue the practice at home. Unfortunately, due to small size of the pilot group the researchers did not compared achieved results with accepted solutions in treatment.

Interactive Medical Productions, LLC has launched the game iGotBalance involving users into interactive process which improves their movement patterns, i.e. balance and stability [22]. Interactive game starts with a template where the user can choose different positions to check his (or her) balance: standing on one leg, with opened or closed eyes, as well set up other parameters. The task is, stabilising a body, to keep a ball in the centre of the circle displayed on the mobile device's screen. This application costs just USD 0,99 [23].

Australian and Singapore researchers present their development in a form of portable, relatively cheap and widely available equipment for the Wii game console - the Wii balance board (WBB) to assess of standing balance [24]. Special software was created for this board to be used onto computers. As one of the shortcomings might be the platform's failure to assess the force in horizontal direction which is required for defining a formula of the balance centre. Researchers concluded that, in comparison with the treatment of recognized devices, this solution can provide a satisfactory quality of the measurement.

J.A.Patterson et al. [25] made the measurement of balance functions by using of tri-axial accelerometer sensors installed in smart phones and later on compared them against measurement results gotten from previously validated Biodex Balance System ${ }^{\mathrm{TM}}$ SD. The scores were similar. It was concluded that their approach can give positive effect to measure and monitor users balance functions. However, while the balance was assessed only in anterior/posterior direction, the further findings are required [25].

Scientists from the University of Sydney developed special iPhone, iPad and iPod compatible educational application to test patients' angular vestibulo-ocular reflex (aVOR) and detect VOR disorders. This tool provides not only testing, but also great teaching and training opportunities in rehabilitation process for patients with vestibular dysfunctions. The application shows to patients what the spring-up of vestibular disorder is and how it ought to be treated [26].

\section{Advances in Latvia and Lithuania}

Pursuant to a big number of patients who do not receive appropriate treatment, care and rehabilitation, 
Rezekne University of Applied Sciences and Siauliai University organized rehabilitation treatment for patients with lower body injuries. Research as well patients' rehabilitation was implemented within MODPART project from January 2012 till December 2013. The project had to encourage persons with disabilities to come back in the labour market. Individual psychophysical, vocational rehabilitation and other health facilitation activities were offered to the patients [27].

During project activity period Biosway system and its features were applied in practice. Researchers developed appropriate methods and technology for the rehabilitation and health improvement. Integrated studies were taken on social and medical rehabilitation to mitigate social risks and facilitate reintegration into the labour market [28, 29, 30].

\section{JUSTIFICATION, PROPOSAL AND DISCUSSIONS}

\section{A. Justification}

Many and many mobile communication devices nowadays are already equipped with different types of tools which are used to determine user's position, deflections, and many other requests. Embedded in mobile phones sensors could be used as testing, training, gaming and entertaining instruments. Companies are started development of modern controllers, mini data processing mother-boards, which allow engineers creating a huge amount and different sorts of interactive devices and systems.

While Raspberry Pi controller (i.e. an analogue of computer's motherboard) is great in the interacting with computers, in gaming and entertainment environment, such as music or Internet browsing, although it is good for other applications, for example, used in weather stations or observation posts, etc., and BeagleBone Black, similarly to Raspberry Pi has a great potential for the hobbyists to construct innovative products [31, 32], Arduino microcontroller is aimed for the purposes which differ from them. While Raspberry $\mathrm{Pi}$, for instance, is a microprocessor based single-board computer, Arduino is a microcontroller based physical computing platform [33]. Arduino costs less than USD 30 which is very affordable price, cheaper than Raspberry $\mathrm{Pi}$ or BeagleBone Black. But main differences which speak for Arduino pick are as follows. Raspberry $\mathrm{Pi}$ and BeagleBone Black are better when a developer plans work on software applications; on the other hand, Arduino is by far better in case of working on hardware projects. Arduino has a real-time capability but Raspberry Pi does not. Arduino has analogue capability that Raspberry Pi does not. So, Arduino is more flexible than other controllers. This gives to Arduino notable advantage in working with any sort of sensors [34]. All that differ Arduino approach from others. From this point of view Arduino features meet better our expectations.

Besides, Arduino microcontrollers attract our attention also thanking to their diverse small sizes and forms which might be used in different applications and conditions $[32,35]$, in particular, where important role is given to sensors, robotics, interactive objects and so on. This, and noted before advantages makes Arduino microcontroller more attractive to be chosen from the set to reach our goal - creating human balance diagnostic system which must be low-cost, affordable, available, user-friendly, reliable, rather sensitive and precise.

\section{B. Proposal}

The idea is to incorporate "Arduino" microcontroller, acceleration sensors, multi-screen digital devices and server into one joint system (Fig. 1).

Acceleration sensors will be attached to patient's body (it could be done either on the head, chest, wrists, shoulders, or other parts of body including lower body ones). Sensors will be wired connected to Arduino microcontroller. This will allow transmitting of the signals from the sensors to controller; as well provide power supply to ensure an operation of these sensors. As an alternative, the wires could be substituted by wireless connections; although, such solution might cause additional questions.

To ensure wireless data transmission between Arduino and digital data processing devices, Bluetooth module will be used and connected to Arduino. To do this, Bluetooth module could be programmed by AT-commands through Bluetooth module's UART interface.

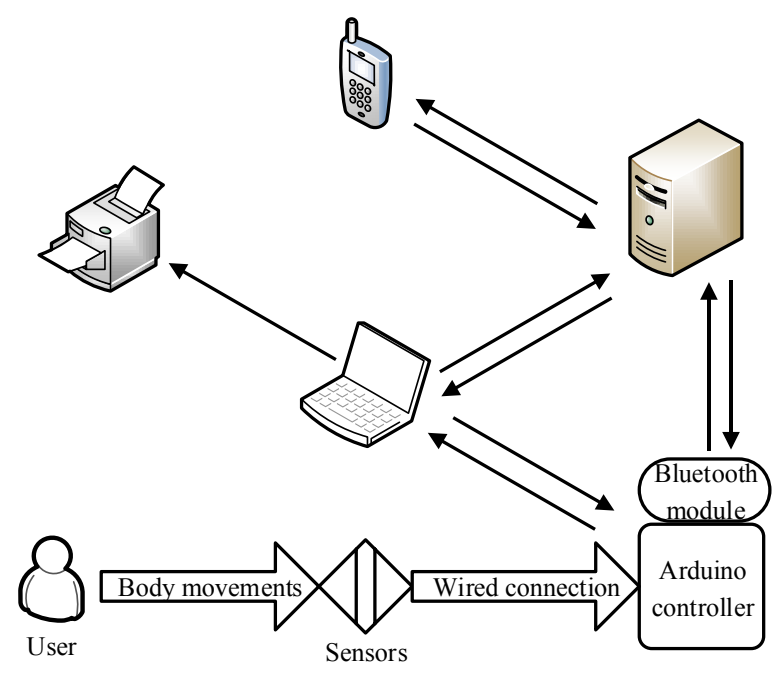

Fig. 1. Human balance diagnostic system proposed model

The data in a form of sensor signals about patient's body movements will be sent through Arduino microcontroller to the server which, depending on patient's needs, will distribute obtained data to the 
computers, laptops, mobile phones and tablets. Patient's movement data, e.g. body deflections, will be stored in the server's database. Computers and laptops might be used as a replacer of the server. In this case all the data will be stored onto hard discs of computers (laptops).

\section{Discussions}

An important thing, which we ought to keep in mind, is the power supply and data transfer. This both issues are closely related. In our case, when acceleration sensors are attached to the body or clothing, sensors power supply issue from energy sources becomes challenging. We can discuss about patient's comfort. On the one hand, the wires really could not be considered as a comfortable dress supplement. On the other hand, independent energy source in a form of battery, powered by DC voltage, could be more comfortable but due to intensive exploitation may request rather frequent battery replacement; besides, it would provoke another problem of sensors data transmitting, but this is not that what we want.

Next challenge might be balance disorder data precision and interpretation. Patient's body starting position and positions during the test, deflections, moving speed, and other parameters are crucial. It is necessary to work out appropriate algorithms to solve this problem.

Developed system expenses are expected to be low. Raw calculation of such costs indicates that we will be able to be in the limits of fifty USD (i.e. Arduino microprocessor - less than USD 30, Bluetooth module - less than USD 10, sensors - less than USD 10 , plus wires or batteries and other fittings). Such price could be considered as a very affordable for almost everybody.

\section{CONCLUSIONS}

At the moment various social and technical solutions are represented in the world to help persons with disabilities, among them - lower body injuries, vestibulo-ocular reflex disorders, other balance dysfunctions. Unfortunately, these solutions in their majority can be used by the narrow spectrum of users because of much orientation of the system developers and sellers on the definite operating systems and devices (first of all, mobile ones); another problem is that technical solutions in a form of equipment, tools and systems, usually offered in the market, are either sensitive and precise but expensive and not affordable, or cheap but not precise enough.

The solution, proposed in this position paper, may solve abovementioned problem. It might be possible to achieve the aim of research - to create a cheap, affordable for everybody and widely available, balance testing and rehabilitation exercises ensuring, progress monitoring, data transmission and processing, easy to use and rather precise tool.

Data measurement precision and interpretation issue might become an integral part of the model's development. As a next step in new system approval would be the comparison of obtained data from new developed system prototype with the data from existing approved body balance testing systems, e.g. Biosway.

\section{$\mathrm{V}$ ACKNOWLEDGMENTS}

This study was partly supported by the National Research Program "Innovative solutions in social rehabilitation in Latvian schools in the context of inclusive education” („Inovatīvi risinājumi sociālajā telerehabilitācijā Latvijas skolās iekḷaujošās izglītības kontekstā - VPP INOSOCTEREHI"); project No.2 „Development, approbation and implementation of new prototypes and innovative methodology (approaches, methods, techniques, ways) in social rehabilitation for the rendering of new services" (,Jaunu prototipu, inovatīvas metodikas (pieeju, metožu, tehniku, paņēmienu) sociālajā rehabilitācijā izstrāde, aprobācija un ieviešana jaunu pakalpojumu sniegšanai”). Contract No. 10-4/VPP-8-7 (RTU PVS ID 1868).

\section{REFERENCES}

[1] The United Nations. Factsheet on Persons with Disabilities, 2015. [Online]. Available: http://www.un.org/disabilities/ default.asp?id=18 [Accessed May 10, 2015].

[2] The World Bank. Disability, Apr. 06, 2015. [Online]. Available: http://www.worldbank.org/en/topic/disability [Accessed May 10, 2015].

[3] Disabled World. Disability Statistics: Facts \& Statistics on Disabilities \& Disability Issues, 2015. [Online]. Available: http://www.disabled-world.com/disability/statistics/ [Accessed May 10, 2015].

[4] M.Živetere, Cilvēku ar îpašām vajadzībām integrācija darba vidē: vadlīnijas, metodiskie materiāli, [Integration of people with disabilities into working environment: guidelines, methodical materials], Riga: ISMA, 2008.

[5] European Disability Forum, "Nothing about us without us", 2013. [Online]. Available: http://www.edf-feph.org/ Page_Generale.asp?DocID=12534 [Accessed Mar. 20, 2015].

[6] W.Oortwijn, E.Nelissen, S.Adamini, S. van den Heuvel, G.Geuskens, L.Burdof, Social determinants state of the art reviews - Health of people of working age - Summary Report, European Commission Directorate General for Health and Consumers, Luxembourg, p. 40, 2011.

[7] UN Economic and Social Council, "Promoting the rights of persons with disabilities and mainstreaming disability in the post-2015 development agenda", United Nations 23rd plenary meeting, Resolution E/RES/2014/6, p. 4, 12 June 2014.

[8] The United Nations. Convention on the Rights of Persons with Disabilities, 2006. [Online]. Available: http://www.un.org/ disabilities/convention/conventionfull.shtml / [Accessed May $10,2015]$

[9] UN General Assembly, "Realization of the Millennium Development Goals and internationally agreed development goals for persons with disabilities: a disability - inclusive development agenda towards 2015 and beyond", Report of the Secretary - General A/67/211, p. 19, 30 July 2012.

[10] European Commission, "EU launches Disability Strategy 2010-2020”, 2010. [Online]. Available: http://ec.europa.eu/ 
social $/$ main.jsp?catId=89\&langId=en\&newsId=933\&furtherN ews $=$ yes. [Accessed Mar. 20, 2015].

[11] I.Skestere, G.Anca, L.Embrekte, M.Gravis, I.Neimane A.Pastore, A.Silina, B.Silina, T.Vahlina, L.Velka, K.AlksneAlksnite, O.Zubkovs, "Koncepcija „Dzīve sabiedrībā”", ["Conception "Life in Society"”], p. 43, 2008. [Online] Available:

http://www.lkndz.lv/lv/box/files/filelists/1290686941koncepcijabrosura.pdf. [Accessed Mar.10, 2015].

[12] D.Winter, "Human balance and posture control during standing and walking," Gait \& Posture, vol.3, no.4, pp. 193 214, 1995.

[13] D.Winter, J.Frank, C.Powell, K.Zabjek, "Unified theory regarding $\mathrm{A} / \mathrm{P}$ and $\mathrm{M} / \mathrm{L}$ balance in quiet stance," Journal of neoropsychology, vol.75, no.6, pp. 2334-2343, 1996.

[14] A.Enders, and Z.Brandt, "Using Geographic Information System Technology to Improve Emergency Management and Disaster Response for People With Disabilities," Journal of Disability Policy Studies, vol.17, no.4, pp. 223-229, 2007.

[15] C.Huang, P.Sue, M.Abbod, B.Jiang, J.Shieh, "Measuring center of pressure signals to quantify human balance using multivariate multiscale entropy by designing a force platform," Sensors, vol. 13, no. 8, pp. 10151-10166, 2013.

[16] Biodex, "Balance System SD", 2015. [Online]. Available: http://www.biodex.com/physicalmedicine/products/balance/balance-system-sd. [Accessed Mar. $12,2015]$.

[17] Biodex, "Operation / Service Manual", Biodex Medical Systems Inc., pp.123, 2014. [Online]. Available: http://www.biodex.com/sites/default/files/950440man_10205r evc.pdf. [Accessed Mar. 12, 2015].

[18] Biodex, "BioSway", 2015. [Online]. Available: http://www.biodex.com/physicalmedicine/products/balance/biosway-portable. [Accessed Mar. $12,2015]$

[19] Biodex, "Balance System and Biosway: Software Manual User's Guide", pp.123, 2014. [Online]. Available: http://www.biodex.com/sites/default/files/950440man_add_14 074.pdf. [Accessed Mar. 12, 2015].

[20] Clear Health Media, "The Easy, Accurate and Low-Cost way to measure subjective visual vertical in your patients", 2015. [Online]. Available: http://www.clearhealthmedia.com/measure-subjective-visualvertical/ [Accessed Jan. 30, 2015].

[21] A.A.Wai, P.D.Duc, C.Syin, H.Zhang, iBEST: Intelligent balance assessment and stability training system using smartphone: Engineering in Medicine and Biology Society (EMBC), the 36th Annual International Conference of the IEEE, pp. 3683 - 3686, Aug. 26-30, 2014, Chicago, USA.

[22] Interactive Medical Productions, LLC, "The iGotBalance App", 2014. [Online]. Available: http://www.igotbalance.com/ [Accessed Jan. 15, 2015].

[23] iTunes, “iGotBalance", 2014. [Online]. Available: https://itunes.apple.com/us/app/ustabilizelite/id435404380?mt=8 [Accessed Jan. 15, 2015].

[24] R.A.Clark, A.L.Bryant, Y.Pua, P.McCrory, K.Bennell, M.Hunt, "Validity and reliability of the Nintendo Wii Balance Board for assessment of standing balance", Gait \& Posture, vol. 31 , pp. 307-310, 2010.
[25] J.A.Patterson, R.Z.Amick, T.Thummar, M.E.Rogers, "Valdation of measures from the smartphone sway balance application: a pilot study", Internation Journal of Sports Physical Therapy (IJSPT), vol. 9, no.2, pp. 135-139, April 2014. [Online]. Available: US National Library of Medicine, National Institutes of Health, http://il.proquest.com. [Accessed Jan. 28, 2015].

[26] H.MacDougall, S.Rogers, "aVOR - angular vestibulo-ocular reflex", 2014. [Online]. Available: https://itunes.apple.com/ us/app/avor/id497245573 $\mathrm{mt}=8$ [Accessed Feb. 26, 2015].

[27] Rezekne University of Applied Sciences and Siauliai University, "LAT-LIT project "Designing a Model Geared towards Participation of People at Social Risk Groups in the Labour Market" (MODPART)", Project index LLIV-223", pp. 3, 2013. [Online]. Available: http:/www.ru.lv/en/research/ scientific_institutes/psri/psri_projects/ [Accessed Nov. 24, 2014].

[28] V.Lubkina, A.Kaupuzs, S.Usca, S., L.Rizakova, A.Ciukmacis, "The testing technology of neuromuscular system, the methodology of its introducting”, pp. 164, 2013. [Online]. Available: http://www.ru.lv/ckfinder/userfiles/RAweb/Saturs/ zinatne/zinatniskie instituti/personas socializacijas petijumu instituts/izdevumi/2014/monografiskie_izdevumi/THE\%20T ESTING\%20TECHNOLOGY\%20OF\%20NEUROMUSCUL ULAR\%20SYSTEM.pdf [Accessed Nov. 24, 2014].

[29] V.Lubkina, A.Kaupuzs, S.Usca, S., L.Rizakova, A.Ciukmacis, "The technology of balance testing and training, the methodology of its introducing", pp. 136, 2013. [Online]. Available:

http://www.ru.lv/ckfinder/userfiles/RAweb/Saturs/zinatne/zina tniskie_instituti/personas_socializacijas_petijumu_instituts/izd evumi/2014/monografiskie izdevumi/THE\%20TECHNOLO GY\%20OF\%20BALANCE\%20TESTING\%20AND\%20TRA INING.pdf [Accessed Nov. 25, 2014].

[30] V.Lubkina, A.Kaupuzs, S.Usca, S., L.Rizakova, A.Ciukmacis, "Methodology of Vibromassage technology and its implementation", pp. 133, 2013. [Online]. Available: http:/www.ru.lv/ckfinder/userfiles/RAweb/Saturs/zinatne/zina tniskie instituti/personas socializacijas petijumu instituts/izd evumi/2014/monografiskie izdevumi/METHODOLLOGY\%20 OF\%20VIBROMASSAGE\%20TECHNOLOGY.pdf [Accessed Nov. 26, 2014].

[31] Raspberry PI, "What is a Raspberry Pi?", 2015. [Online]. Available: http://www.raspberrypi.org/help/what-is-araspberry-pi/ [Accessed Feb. 27, 2014].

[32] D.Norris, The Internet of Things: Do-It-Yourself at Home Projects for Arduino, Raspberry Pi, and BeagleBone Black, San Francisco: McGrow-Hill Education, 2015.

[33] R.Adams, "What are the differences between Arduino and Raspberry Pi?", 2015. [Online]. Available: http://www.quora.com/ What-are-the-differences-betweenArduino-and-Raspberry-Pi [Accessed Mar. 18, 2015].

[34] L.Orsini, "So you want to get into DIY hacking. Which device should you buy?", 2015. [Online]. Available: http://readwrite.com/2014/05/07/arduino-vs-raspberry-piprojects-diy-platform [Accessed Mar. 18, 2015].

[35] T.Olsson, Arduino Wearables, Berkley, CA: APress, 2012. 